\title{
Pengembangan Modul Mata Kuliah Sejarah Pendidikan Islam Di Sekolah Tinggi Ilmu Tarbiyah Pemalang
}

\begin{abstract}
Nisrokhah*
Abstract: This research is the development of research is a study to produce a product in the form of modules History of Islamic Education. The purpose of this research is to develop a module that is suitable for studying the subjects history of Islamic education in improving the quality of learning outcomes. The module is designed to be able to learn independently and conventional. In developing this module uses Instructional Development Model in starting to identify instructional needs in preparing the design and carry out formative evaluation and summative evaluation to determine learning outcomes in using the module . Results of this study found that the modules developed fit the needs of students of the School of Pemalang
\end{abstract}

Keywords: conventional,self of contained, modules, development.

Abstrak: Penelitian ini berupa penelitian pengembangan yaitu suatu penelitian untuk menghasilkan suatu produk dalam bentuk modul Sejarah Pendidikan Islam. Tujuan penelitian ini adalah mengembangkan modul yang sesuai untuk mempelajari mata kuliah sejarah pendidikan islam dalam meningkatkan mutu hasil belajar. Modul dirancang untuk dapat mempelajarinya secara mandiri dan konvensional. Dalam mengembangkan modul ini menggunakan Model Pengembangan Instruksional di mulai dari Mengidentifikasi kebutuhan instruksional sampai pada menyusun desain dan melaksanakan evaluasi formatif serta dilakukan evaluasi sumatif untuk mengetahui hasil belajar dalam menggunakan modul . Dari penelitian ini didapati hasil bahwa modul yang dikembangkan cocok atau sesuai dengan kebutuhan mahasiswa Sekolah Tinggi Ilmu Tarbiyah Pemalang.

Kata kunci: Konvensional, Mandiri, Modul, Pengembangan.

\section{PENDAHULUAN}

Mata kuliah sejarah pendidikan islam merupakan mata kuliah yang membahas secara komprehensif mengenai perkembangan pendidikan islam dari masa lalu hingga masa sekarang serta dampak aplikasinya dalam pendidikan dan pembelajaran. Agar proses pembelajaran tersebut menarik dan menyenangkan diperlukan strategi dalam penyampaian mata kuliah karena mata kuliah ini dianggap mata kuliah yang monoton yang hanya terbatas pada penyampaian materi yang hanya berisi cerita tentang sejarah pendidikan islam. Sehingga berdampak pada hasil belajar, sebagian dari mereka rata-rata nilai pada mata kuliah sejarah pendidikan islam hasilnya minimal $\mathrm{B}+$ dan sebagian besar mereka mendapat A, karena ketika ujian mereka lebih ditekankan pada aspek kognitif saja atau lebih banyak hafalan yang sifatnya teoritis. Dari hasil studi pendahuluan yang dilakukan peneliti ditemukan salah satu faktor yang mempengaruhi hasil belajar tersebut adalah faktor minimnya fasilitas pendukung seperti terbatasnya bahan pembelajaran salah satunya adalah modul. terhadap 32 mahasiswa didapati hasil 62, $5 \%$ membutuhkan modul dan 37,5 $\%$ tidak membutuhkan modul. Modul merupakan unit yang lengkap yang berdiri sendiri dan terdiri atas suatu rangkaian kegiatan belajar yang disusun untuk membantu siswa mencapai sejumlah tujuan yang

* Nisrokhah Dosen di Sekolah Tinggi Ilmu Tarbiyah Pemalang, Klegen Comal, Pemalang 52363, Telepon: 085742807459Email: nisrokhaabduh@yahoo.co.id 
dirumuskan secara khusus dan jelas. (S. Nasution, 2008:205)

Dalam buku lain menyebutkan modul dapat diartikan sebagai satuan program pembelajaran terkecil yang dapat dipelajari oleh peserta didik secara perseorangan (self instuction) (Andi Prastowo, 2011:105); Modul dapat juga diartikan sebagai bahan belajar yang dirancang secara sistematis berdasarkan kurikulum tertentu dan dikemas dalam bentuk satuan pembelajaran terkecil dan memungkinkan dipelajari secara mandiri dalam satuan waktu tertentu (Purwanto, dkk., 2007: 9). Modul adalah sebuah buku yang ditulis dengan tujuan agar peserta didik dapat belajar secara mandiri tanpa atau dengan bimbingan guru.(Abdul Majid, 2011:176). Dari beberapa pengertian modul diatas dapat disimpulkan bahwa modul dapat digunakan secara mandiri dan juga dengan bimbingan dosen atau konvensional.

Bahan pembelajaran ini menjadi sangat penting karena merupakan satu kesatuan program yang dapat mengukur tujuan. Tujuan utama sistem modul adalah untuk meningkatkan efisiensi dan efektifitas pembelajaran di sekolah, baik waktu, dana, fasilitas, maupun tenaga guna mencapai tujuan secara optimal. Selain itu sebagaimana dirumuskan oleh Purwanto dkk Tujuan disusunnya modul ialah agar peserta didik dapat menguasai kompetensi yang diajarkan dalam diklat atau kegiatan pembelajaran dengan sebaik-baiknya. (Purwanto dkk, 2007:10)

Modul juga dapat disusun untuk keperluan belajar mandiri, yaitu suatu sistem yang dapat dipandang sebagai struktur, proses maupun produk. Sebagai suatu struktur maksudnya adalah suatu susunan dengan hierarki tertentu.(Yusuf Hadi Miarso, 2011:251)

Modul memiliki beberapa fungsi diantaranya: (1) Bahan ajar mandiri. Penggunaan modul dalam proses pembelajaran berfungsi meningkatkan kemampuan peserta didik untuk belajar sendiri tanpa tergantung kepada kehadiran pendidik; (2) Pengganti fungsi pendidik. Modul sebagai bahan ajar yang harus mampu menjelaskan materi pembelajaran dengan baik dan mudah dipahami oleh peserta didik sesuai tingkat pengetahuan dan usia mereka; (3) Sebagai alat evaluasi. Modul menuntut peserta didik untuk dapat mengukur dan menilai sendiri tingkat penguasaannya terhadap materi yang telah dipelajari; (4) Sebagai bahan rujukan bagi peserta didik. Modul mengandung berbagai materi yang harus dipelajari oleh peserta didik. (Andi Prastowo,2011: 107-108) . Modul dapat dibedakan berdasarkan jenisnya yang dapat dilihat dari penggunaanya dan penyusunannya. Pertama menurut penggunaanya, modul terbagi menjadi dua macam yaitu modul untuk peserta didik dan modul untuk pendidik. Modul untuk peserta didik berisi kegiatan belajar yang dilakukan oleh peserta didik, sedangkan modul untuk pendidik berisi petunjuk pendidik, tes akhir modul dan kunci jawaban tes akhir modul.

Kedua Menurut Tujuan penyusunannya, Modul dapat dibedakan menjadi dua jenis yaitu modul inti (modul dasar) dan modul pengayaan. Modul inti adalah modul yang disusun dari kurikulum dasar, yang merupakan tuntutan dari pendidikan dasar umum yang diperlukan oleh seluruh warga indonesia. Modul pengajaran ini merupakan hasil penyusunan dari unit-unit program yang disusun menurut tingkat (kelas) dan bidang studi (mata pelajaran). Sedangkan modul pengayaan disusun sebagai bagian dari usaha untuk mengakomodasi peserta didik yang telah menyelesaikan dengan baik program pendidikan dasarnya mendahului teman-temannya. Dalam penelitian ini secara khusus modul yang akan dikembangkan adalah modul yang digunakan untuk peserta didik atau mahasiswa di Sekolah Tinggi Ilmu Tarbiyah Pemalang semester 2 dalam mempelajari mata kuliah Sejarah Pendidikan Islam.

Modul sebagai bahan pelajaran mandiri memiliki ciri-ciri sebagai berikut: 1) belajar mandiri, bahan pelajaran disusun sedemikian rupa sehingga pembelajar dapat memahaminya tanpa atau sedikit mungkin bantuan orang lain. (Sitepu, 2006:109) Agar pembelajar dapat belajar mandiri dengan menggunakan modul, maka disamping selengkap dan sejelas mungkin,modul disertai bahan evaluasi yang memungkinkan pembelajar dapat mengukur sendiri hasil belajarnya; 2) tuh yaitu Bahan masing-masing unit pelajaran disusun secara utuh untuk mencapai suatu kompetensi dasar atau indikator kompetensi. Dengan demikian pemelajar mempelajari bahan pelajaran dari suatu modul secara lengkap dan tuntas;(3) Berdiri sendiri artinya disamping memuat bahan pelajaran yang lengkap untuk setiap unit, modul merupakan paket belajar yang berdiri sendiri dan tidak tergantung pada media lain;(3) Dapat disesuaikan isi (perangkat lunak) dan media (perangkat keras) yang dapat digunakan dapat segera disesuaikan dengan perkembangan ilmu pengetahuan 
dan teknologi; (4) Akrab dengan pemakainya yaitu media yang digunakan mudah dioperasikan, intruksikan yang disampaikan mudah dimengerti dan mudah ditanggapi oleh pembelajar, bahasa yang digunakan adalah besifat umum, sederhana dan mudah dimengerti oleh pembelajar. Media, penyajian bahan pelajaran dan bahasa yang dipergunakan membuat pembelajar merasa akrab dengan modul serta termotivasi untuk mempelajarinya.

Modul sebagai bahan pembelajaran untuk keperluan bahan ajar secara konvensional memiliki ciri-ciri ; (1) Berisi pesan.Pesan yang dimaksud ialah bahan pembelajaran yang harus dipelajari oleh peserta didik;(2) Sistematis, Urutan konsep atau materi ditata berdasarkan struktur pengetahuan atau ketrampilan tertentu dengan urutan yang memudahkan pembelajar memperoleh kompetensi yang diharapkan;(3) Menggunakan prinsip-prinsip didaktik metodik, Dalam penyusunan modul dikemas bedasarkan teori belajar dan pembelajaran yang sesuai dengan sifat pengetahuan atau ketrampilan tertentu, sesuai karakteristik pembelajar; (4) Relevansi, Disusun sesuai untuk mencapai tujuan pembelajaran;(5) Bersifat khusus, artinya dirancang khusus untuk tujuan tertentu untuk pembelajar dengan ciri tertentu serta dalam lingkungan dan waktu belajar dan pembelajaran tertentu pula. (Sitepu, 2006:1) Dari ciri tersebut dapat disimpulkan bahwa dalam penelitian ini akan disusun modul atau bahan pembelajaran secara mandiri dan secara konvensional dalam mempelajari mata kuliah sejarah pendidikan islam di Sekolah Tinggi Ilmu Tarbiyah.

Sistematika modul terdiri dari tiga bagian utama yaitu Bagian awal modul berisi pendahuluan, bagian inti berisi bahan pelajaran, dan bagian akhir modul berisi tes sumatif;(1) Bagian awal memberikan informasi umum tentang bahan pelajaran, kegunaan, tujuan pembelajaran umum, susunan dan keterkaitan antar judul modul, bahan pendukung lainnya dan petunjuk untuk mempelajari modul;(2) Bagian inti terdiri atas unit-unit pelajaran. Masing-masing unit terdiri atas pendahuluan, kegiatan belajar, dan daftar pustaka. Pendahuluan berisi cakupan materi (Deskripsi singkat), tujuan pembelajaran khusus, perilaku/kemampuan awal, manfaat dan urutan pokok bahasan secara logis dan petunjuk belajar/ cara mempelajari modul, Kegiatan belajar mencakup uraian bahan ajar contoh-contoh, latihan, rangkuman, tes formatif dan kunci jawaban, Daftar Pustaka berisi daftar sumber dan bacaan yang dapat dipergunakan pembelajar untuk memperkaya isi pokok bahasan. Bagian akhir berisi penutup modul,glosarium, dan lampiran-lampiran yang terkait dengan modul

Modul sebagai salah satu bahan atau media cetak dalam proses belajar mengajar memiliki kelebihan dan keterbatasan modul. Modul memiliki kelebihan sebagai berikut: (1)Menentukan kecepatan sendiri. Para siswa bisa menyelesaikan materi berdasarkan kecepatan mereka sendiri; (2) Tervalidasi. Modulmodul diuji dan divalidasi sebelum disebarkan. (Smaldino,2011:280);(3) Bentuk fisiknya mudah dibawa-bawa, memudahkan pengguna untuk membacanya sewaktu-waktu kapan saja dan dimana saja.; (4) Ekonomis, mudah pendistribusiannya, serta mudah untuk dipindah-pindah; (5)Pembaca diberi kesempatan untuk mencerna isi informasi yang terkandung didalamnya; (6)Memungkinkan pembaca mengulang-ulang bacaannya oleh karena itu pembaca bisa mengulang hal-hal penting yang sebelumnya terlewati; (7) Mampu menghasilkan kesamaan pengertian terhadap informasi yang terkandung didalamnya (Benny A. Pribadi \& Yuni Katrin, 2009:8). Keterbatasan Modul : (1) Kualitas modul,kualitas modul bervariasi; beberapa diantaranya merupakan modul latihan dan praktik yang tidak menginspirasi dan berkualitas rendah; (2) Tidak dapat menampilkan gerak dan suara, penulis sudah berusaha menggambarkan dalam tulisan; (3) Modul dengan bahan cetak terbuat dari kertas, apabila kualitasnya jelek maka cepat rusak dan tidak tahan air.

Merujuk pada analisis tersebut rumusan masalah dalam penelitian ini adalah modul seperti apakah yang sesuai untuk mempelajari mata kuliah sejarah pendidikan islam untuk meningkatkan mutu hasil belajar mahasiswa Sekolah Tinggi Ilmu Tarbiyah Pemalang?

Berdasarkan latar belakang diatas, maka Tujuan penelitian pengembangan ini adalah untuk mengembangkan modul yang sesuai untuk mempelajari mata kuliah sejarah pendidikan islam dalam meningkatkan mutu hasil belajar mata kuliah sejarah pendidikan islam. Secara teoritis, temuan dalam penelitian ini diharapkan dapat memberikan masukan dalam pengembangan bahan pembelajaran, agar proses pembelajaran dapat tercapai sesuai dengan tujuan yang diinginkan. Secara praktis, hasil penelitian ini diharapkan dapat menjadi acuan dalam 
proses pembelajaran yang dapat diterapkan oleh para dosen dan meningkatkan efektifitas pembelajaran sejarah pendidikan islam.

\section{METODE PENELITIAN}

Penelitian ini berupa penelitian pengembangan atau (development research) yaitu suatu proses atau langkah-langkah untuk mengembangkan suatu produk baru atau menyempurnakan produk yang telah ada, yang dapat dipertanggungjawabkan. Penelitian ini menghasilkan modul pembelajaran untuk mempelajari mata kuliah sejarah pendidikan islam. Modul ini ditujukan agar memberikan kesempatan kepada mahasiswa untuk dapat mempelajari modul ini secara mandiri dan konvensional.

Untuk menghasilkan modul pembelajaran peneliti melakukan prosedur pengembangan dengan menggunakan Model Pengembangan Instruksional(MPI) yaitu: (1)Mengidentifikasi kebutuhan instruksional dan menulis tujuan instruksional umum; (2)Melakukan analisis instruksional; (3)Mengidentifikasi perilaku dan karakteristik awal peserta didik; (4)Menulis Tujuan Instruksional Khusus ( TIK); (5)Menulis Tes Acuan Patokan; (6)Mengembangkan Strategi Instruksional; (7)Mengembangkan Bahan Instruksional; Menyusun desain dan melaksanakan evaluasi formatif yang termasuk dalamnya kegiatan merevisi. (M.Atwi Suparman, 2012:116). Instrumen pengumpulan data adalah bahan ajar berupa modul Sejarah Pendidikan Islam, kuesioner/angket dan tes pengukuran tingkat kognitif hasil produk.

\section{Validasi, Evaluasi dan Revisi}

Setelah modul selesai dibuat dan sebelum diuji-cobakan ke kelas, maka dilakukan evaluasi terlebih dahulu dengan melibatkan evaluasi ahli yang kompeten di bidang Sejarah Pendidikan Islam. Para ahli tersebut adalah yang kompeten di bidangnya yaitu, ahli materi sejarah pendidikan islam, dan teman sejawat.

Ahli materi adalah orang yang berkompeten dalam menguasai konsep materi Sejarah Pendidikan Islam terdiri dari 2 orang yang memiliki disiplin ilmu dalam bidang Sejarah Pendidikan Islam. Pada tahapan ini ahli pakar materi memberikan penilaian dengan menggunakan instrument yang telah dibuat. Teman Sejawat adalah orang yang berkompeten menguasai secara praktis teori dalam proses belajar mengajar.
Evaluasi selanjutnya evaluasi satu-satu(one to one), evaluasi kelompok kecil dan uji coba lapangan pada kelompok besar.

Skala penilaian yang digunakan pada masing-masing instrumen untuk menguji bahan ajar pembelajaran terdiri dari empat kategori yang telah diatur oleh peneliti berdasarkan pada kriteria interpretasi skor untuk skala Likert yaitu : Skor 4=Sangat Setuju; Skor 3=Setuju; Skor 2= Kurang Setuju; Skor 1=Tidak Setuju, Batas baik dan tidaknya kualitas modul pembelajaran sejarah pendidikan islam dapat dijadikan sebagai alternatif sumber pendukung pembelajaran. Adapun kriteria interpretasi skornya adalah $0 \%-25 \%=$ Sangat kurang baik; $26 \%-50 \%=$ Kurang baik; $51 \%-75 \%=$ Baik; $76 \%-100 \%=$ Sangat Baik.

Sebelum instrumen test hasil belajar Sejarah Pendidikan Islam digunakan sebagai alat pengumpul data pada evaluasi sumatif, maka terlebih dahulu diketahui validitas dan Reliabilitas untuk mengetahui sejauhmana ketepatan dan kecermatan suatu alat ukur. Uji validitas instrumen tes hasil belajar dilakukan dengan menggunakan rumus korelasi point biserial. Untuk menguji reliabilitas menggunakan KR-20. Untuk menilai kwalitas produk modul yang dengan menggunakan angket, angket tersebut berbentuk pilihan yang harus di check list (v) dengan empat pilihan jawaban. Untuk validitas instrumen penilaian modul dalam bentuk skala likert maka digunakan rumus korelasi product moment dan untuk menghitung reliabilitas digunakan rumus Alpha Cronbach. Selanjutnya dilakukan Uji t -tes untuk uji signifikansi antara pre test dan Post test untuk mengetahui taraf signifikansi terhadap hasil belajar antara sebelum menggunakan modul dan sesudah menggunakan modul.

\section{HASIL PENELITIAN DAN PEMBAHASAN}

Penelitian ini menghasilkan modul Sejarah Pendidikan Islam dengan harapan modul ini membantu mahasiswa dalam mempelajari mata kuliah Sejarah Pendidikan Islam. Sebelum menghasilkan modul, peneliti melakukan penelitian pendahuluan untuk mengetahui tingkat kebutuhan mahasiswa dan kesulitan yang dialami mahasiswa ketika mempelajari mata kuliah Sejarah Pendidikan Islam dilakukan dengan menyebarkan angket atau kuesioner. Quesioner disebarkan kepada 32 mahasiswa hasil kuesioner pada penelitian pendahuluan pada 32 
mahasiswa menghasilkan 62,5 \% membutuhkan modul dan 37,5 \% tidak membutuhkan modul. Lalu peneliti melakukan analisis bahwa modul yang cocok untuk mahasiswa Sekolah Tinggi Ilmu Tarbiyah Pemalang adalah sebuah modul dengan metode pembelajaran secara mandiri dan konvensional karena perkuliahan yang dilakukan selama ini bersifat monoton dan pembelajaran diperlukan sebuah sumber belajar berupa modul yang dapat membantu pemahaman mahasiswa terhadap mata kuliah Sejarah Pendidikan Islam.

Sebelum merancang modul peneliti melakukan analisis kurikulum yaitu bahwa mata kuliah Sejarah Pendidikan Islam adalah mata kuliah prasyarat sebelum mengikuti mata kuliah Ilmu Pendidikan Islam dan harus lulus mata kuliah umum dengan berat 2 sks, mata kuliah Sejarah Pendidikan Islam diberikan pada mahasiswa semester 2 atau genap. Perkuliahan Sejarah Pendidikan Islam ditempuh dengan 12 materi atau pokok bahasan.

Desain dan rancangan modul Sejarah Pendidikan Islam yang dikembangkan sudah sesuai dengan kebutuhan dan karakteristik mahasiswa Sekolah Tinggi Ilmu Tarbiyah Pemalang, yaitu dilihat dari isi, Penyajian, Bahasa dan Grafika. Dari segi isi Modul yang dikembangkan sudah sesuai yaitu: (1) kesesuaian uraian materi dengan standar kompetensi atau SK dari kompetensi dasar atau KD yang terdapat dalam kurikulum mata kuliah yang bersangkutan; (2)Keakuratan materi; dan (3) materi pendukung pembelajaran (Masnur Muslich, 2010 :292). Dari indikator tersebut didapati hasil penilaiannya bahwa modul yang dikembangkan dari segi isi dalam kategori sangat baik dengan prosentase skor rata-rata $84,72 \%$.

Dari segi penyajian ada tiga indikator dalam penilaian kelayakan penyajian: (1)Teknik penyajian; (2)Penyajian Pembelajaran; dan (3)Kelengkapan Penyajian. Teknik penyajian meliputi: Sistematika penyajian, keruntutan penyajian, keseimbangan antar bab, indikator ini mendapatkan penilaian 95,83\% yang termasuk dalam kategori sangat baik sesuai dengan indikator yang dinilai. Penyajian pembelajaran meliputi: berpusat pada siswa, mengembangkan ketrampilan proses, memperhatikan aspek keselamatan kerja, indikator ini mendapatkan penilaian 91,66\% yang termasuk dalam kategori sangat baik sesuai dengan indikator yang dinilai. Kelengkapan penyajian meliputi : (a) Bagian pendahuluan memuat prakata, petunjuk penggunaan dan daftar isi;(b)Bagian isi memuat Gambar, ilustrasi, tabel, rujukan/sumber acuan, soal latihan atau rangkuman setiap bab.(c) Bagian penutup/ penyudah memuat daftar pustaka, daftar istilah (Glosarium) atau petunjuk pengerjaan jawaban soal latihan terpilih.Indikator ini mendapatkan penilaian $89,06 \%$ yang termasuk dalam kategori sangat baik sesuai dengan indikator yang dinilai.

Dari segi bahasa dalam penilaian uji kelayakan bahasa ada tiga indikator yang dinilai; (1) Kesesuaian pemakaian bahasa dengan tingkat perkembangan siswa indikator ini mendapatkan penilaian 93,75\% yang termasuk dalam kategori sangat baik sesuai dengan indikator yang dinilai. (2) Pemakaiaan bahasa yang komunikatif indikatornya meliputi : (a) Keterbacaan pesan ;(b) Ketepatan kaidah bahasa indikator ini mendapatkan penilaian 93,75 \% yang termasuk dalam kategori sangat baik sesuai dengan indikator yang dinilai.; (3) Pemakaian bahasa memenuhi syarat keruntutan dan keterpaduan alur berpikir meliputi (a) keruntutan dan keterpaduan antar bab; (b) keruntutan dan keterpaduan antar paragraf.Indikator ini mendapatkan penilaian 93,75 $\%$ yang termasuk dalam kategori sangat baik sesuai dengan indikator yang dinilai. Dilihat segi kegrafikan ada 3 indikator yang dinilai yaitu (1) Ukuran buku; (2) Desain kulit buku; dan (3) Desain isi buku.

Menentukan ukuran buku harus memperhatikan faktor kepraktisan penggunaannya dan juga faktor lain yang harus diperhatikan seperti jenis informasi yang disampaikan, sasaran pembaca, kesukaan pembaca, biaya produksi dan pemasaran, ukuran kertas yang standar dan efisiensi penggunaan bahan produksi,seperti kertas dan tinta cetak. (BP.Sitepu, 2012:128). Agar kertas tidak banyak terbuang, ukuran buku mengacu pada standar ukuran kertas yang ditetapkan oleh International Organization for Standardization (ISO). Ukuran buku dibedakan antara yang berbentuk vertikal/potret/tegak, horizontal/landscape/baring, dan oblong/simetris. Ukuran buku bergantung pada jenis/isi buku serta sasaran pembaca.

Ukuran modul yang dirancang dalam penelitian ini yaitu sesuai standar ISO berukuran B5 (176 x 250) (mm) dengan toleransi perbedaan ukuran antara 0-20 mm dengan ketebalan 157 halaman dengan bentuk Vertikal/potret/tegak (BP. Sitepu, 2006:102) dan ukuran buku sesuai dengan materi isi buku 
karena akan berpengaruh pada tata letak bagian isi dan jumlah halaman buku. Indikator ini mendapatkan penilaian 93,75 \% yang termasuk dalam kategori sangat baik sesuai dengan indikator yang dinilai.

Desain kulit buku meliputi (a) tata letak; (b) Tipografi Kulit Buku; (c) Penggunaan huruf. Tata letak meliputi: Penampilan unsur tata letak pada kulit muka, belakang, dan punggung secara harmonis memiliki irama dan kesatuan serta konsisten; elemen warna, ilustrasi dan tipografi ditampilkan secara harmonis dan saling terkait satu dan lainnya; Ukuran huruf yang lazim untuk buku teks pelajaran adalah 10, 11, dan 12 point. Untuk catatan-catatan tertentu kadang-kadang dipakai huruf dengan ukuran 6 atau 8 point yang terlalu kecil untuk dapat dibaca dengan mudah.

Ukuran huruf 24 point biasanya dipakai untuk judul, ukuran 22 point untuk subjudul.Ukuran huruf yang sama dengan jenis huruf yang berbeda dapat memberikan tampilan yang berbeda. Dalam memilih ukuran huruf yang perlu diperhatikan adalah dapat memuat banyak kata dalam satu baris tanpa melanggar ketentuan jumlah huruf dalam satu baris. Kemudian memperhatikan keseimbangan antara spasi kata dengan spasi baris. Modul yang dirancang dalam penelitian ini isi teks menggunakan huruf book antiqua dengan ukuran font 11. Indikator ini mendapatkan penilaian 84,38 \% yang termasuk dalam kategori sangat baik sesuai dengan indikator yang dinilai.

Tipografi Kulit Buku meliputi: Huruf yang digunakan menarik dan mudah dibaca; Ukuran huruf judul buku lebih dominan dan proporsional dibandingkan (ukuran buku, nama pengarang dan penerbit); Warna judul buku kontras dengan warna latar belakang. Penggunaan huruf meliputi: Huruf yang digunakan mudah dibaca, huruf yang digunakan tidak melelahkan mata, huruf yang digunakan menarik untuk dibaca. Indikator ini mendapatkan penilaian $100 \%$ yang termasuk dalam kategori sangat baik sesuai dengan indikator yang dinilai. Desain isi buku Indikator pemakaian bahasa yang komunikatif diarahkan pada hal-hal seperti pencerminan isi buku yang meliputi: Menggambarkan isi/materi ajar dan mengungkapkan karakter obyek; Bentuk, warna, ukuran, proporsi obyek sesuai realita sehingga tidak menimbulkan salah penafsiran maupun pengertian siswa. Untuk menghasilkan modul, peneliti melakukan langkah-langkah pengembangan dengan
Model Pengembangan Instruksional dengan langkah sebagai berikut:

Langkah Pertama yaitu Identifikasi kebutuhan instruksional dan menulis tujuan instruksional umum ( TIU). Identifikasi kebutuhan instruksional bertujuan untuk mengetahui kebutuhan mahasiswa dalam proses belajar mengajar. Dalam penelitian ini yang akan diteliti adalah dalam proses pembelajaran mata kuliah Sejarah Pendidikan Islam, mata kuliah ini menjadi sorotan karena dianggap mata kuliah yang membosankan, mudah dipelajari tetapi dari segi afektif atau sikap mahasiswa kurang dapat menerapkan. Selanjutnya menulis tujuan instruksional umum (TIU). Dari kegiatan mengidentifikasi kebutuhan instruksional diperoleh jenis pengetahuan, ketrampilan, dan sikap yang tidak pernah dipelajari atau belum dilakukan dengan baik oleh mahasiswa. Jenis pengetahuan, ketrampilan, dan sikap tersebut masih bersifat umum atau garis besar. Ia merupakan hasil belajar yang diharapkan dikuasai mahasiswa setelah menyelesaikan program pendidikan. Hasil belajar ini disebut tujuan instruksional.

Modul sejarah pendidikan islam yang dirancang memiliki tujuan instruksional umum yaitu menerapkan system pendidikan islam dari masa lalu sampai masa sekarang dalam rancang bangun sistem pendidikan islam.

Langkah kedua yaitu melakukan analisis Instruksional yaitu proses menjabarkan perilaku umum menjadi perilaku khusus yang tercantum secara logis dan sistematis. Kegiatan tersebut untuk dimaksudkan untuk mengidentifikasi perilakuperilaku khusus yang menggambarkan perilaku umum secara lebih terperinci. Langkah ketiga yaitu mengidentifikasi perilaku dan karakteristik awal mahasiswa. Mahasiswa yang mengikuti mata kuliah Sejarah Pendidikan Islam disediakan bagi mahasiswa dengan syarat sebagai berikut: Terdaftar sebagai mahasiswa Sekolah Tinggi Ilmu Tarbiyah( STIT ) Pemalang pada semester ini di jurusan S1 Pendidikan Agama Islam semester II, Mata kuliah ini sebagai mata kuliah prasyarat untuk mengikuti mata kuliah Ilmu Pendidikan islam, mahasiswa sudah lulus mata kuliah umum ( MKU) dengan nilai minimal $\mathrm{B}+$. Mahasiswa yang akan mengikuti mata kuliah ini belum pernah mengikuti mata kuliah sejarah pendidikan islam, karena mata kuliah ini merupakan mata kuliah khusus setelah mereka sudah lulus mengikuti mata kuliah umum (MKU). Sehingga 
mahasiswa benar-benar baru mengenal mata kuliah Sejarah Pendidikan Islam.

Karakteristik Awal Mahasiswa bahwa Mahasiswa semester 2 rata- rata mereka berusia antara 18-25 tahun. Masa ini masuk kedalam masa dewasa dini. (Istilah adult berasal dari kata kerja latin, seperti juga istilah adolescene-adolescere yang berarti "tumbuh menjadi kedewasaan" Orang dewasa adalah individu yang telah menyelesaikan pertumbuhannya dan siap menerima kedudukan dalam masyarakat bersama dengan orang dewasa lainnya. (Elizabeth Harlock, 2006: 246)

Asumsi Mahasiswa yang pernah mengikuti mata kuliah Sejarah Pendidikan islam memiliki mind set atau pola pikir bahwa mata kuliah sejarah pendidikan islam lebih banyak bersifat kognitif atau pengetahuan saja, dan dalam pembelajarannya lebih didominasi oleh dosen, sehingga mahasiswa kurang memiliki ruang gerak dalam proses pembelajarannya.

Langkah keempat yaitu Menulis Tujuan Instruksional Khusus ( TIK). Tujuan Instruksional khusus harus mengandung unsur-unsur yang dapat memberikan petunjuk kepada penyusun tes agar dapat mengembangkan tes yang benar-benar dapat mengukur perilaku yang terdapat didalamnya. Unsur-unsur itu dikenal dengan ABCD yang berasal dari empat kata sebagai berikut: $\mathrm{A}=$ Audience adalah mahasiswa yang akan belajar, yaitu mahasiswa S1 Program Studi Pendidikan Agama Islam semester 2; $\mathrm{B}=$ Behavior adalah perilaku yang spesifik yang akan dimunculkan oleh mahasiswa setelah selesai proses belajarnya dalam pelajaran tersebut; $\mathrm{C}=$ Condition. Komponen ketiga dalam TIK adalah C (Condition). C adalah kondisi yang berarti batasan yang dikenakan kepada mahasiswa atau alat yang digunakan mahasiswa saat ia dites; $\mathrm{D}=$ Degree adalah tingkat keberhasilan mahasiswa dalam mencapai perilaku tersebut.

Langkah kelima yaitu Menulis Tes Acuan Patokan pada tahap ini peneliti melakukan langkahlangkah seperti berikut:

Tahap pertama, menentukan maksud tes, tes yang akan disusun oleh pengembang instruksional akan digunakan untuk dua maksud utama yaitu sebagai berikut: (1) Memberikan umpan balik bagi mahasiswa tentang hasil belajar mahasiswa dalam setiap tahap proses belajarnya; (2) Menilai efektifitas sistem instruksional secara keseluruhan. Untuk ini pengembang instruksional menyusun Tes
Acuan Patokan yang dapat mengukur hasil belajar mahasiswa dalam menguasai seluruh perilaku dalam Tujuan Instruksional Umum dan sampel perilaku dalam Tujuan Instruksional Khusus. Tahap kedua; Membuat tabel spesifikasi untuk setiap tes untuk butir 1a dan 1 b yang terdiri atas empat kolom, yaitu : daftar perilaku, persentase jenis tes, dan jumlah butir tes.

Langkah ke enam : Mengembangkan Strategi Instruksional Strategi Instruksional berkenaan dengan pendekatan pengajaran dalam mengelola kegiatan instruksional untuk menyampaikan materi atau isi pelajaran secara sistematis, sehingga kemampuan yang diharapkan dapat dikuasai oleh mahasiswa secara efektif dan efisien. Langkah ke Tujuh: mengembangkan bahan instruksional . Pada tahap ini peneliti mengembangkan bahan yang dibutuhkan mulai dari mengumpulkan referensi berkaitan dengan materi yang akan dimuat dalam modul; Menelaah referensi yang sudah ada; Membuat kerangka naskah; Mengembangkan kerangka naskah ; Membuat pola naskah yang akan dimuat dalam modul ; Melengkapi ilustrasi ; Mengoreksi kerangka naskah ; Mendesain cover modul depan; punggung dan belakang ; Bekerjasama dengan ahli materi untuk memberikan masukan dan menilai hasil dari naskah yang disusun; Bekerjasama dengan teman sejawat untuk memberikan masukan berkaitan dengan penyajian dan metode yang digunakan dalam modul tersebut; Melakukan revisi terhadap naskah dari hasil penilaian ahli materi dan teman sejawat.

Langkah ke Delapan : Menyusun desain dan melaksanakan evaluasi formatif (Atwi Suparman, 2004:276). Setelah naskah berhasil disusun maka dilakukan uji coba adapun tahapan uji coba sebagai berikut: Telaah pakar yang meliputi Ahli materi dan Teman sejawat.

Ahli Materi terdiri dari 2 orang yang ahli dan kompeten dalam menguasai sejarah pendidikan islam mereka adalah dosen Sekolah Tinggi Agama Islam (STAIN ) Pekalongan yang memiliki disiplin ilmu dalam bidang sejarah pendidikan islam serta memiliki pengalaman mengajar sejarah pendidikan islam.Ahli materi yang menjadi validator adalah Drs.H. Ahmad Zaeni, M.Ag. dan Dwi Istiya, M.Ag. 
Tabel 3. Skor Prosentase penilaian Ahli Materi modul Sejarah Pendidikan Islam

\begin{tabular}{|c|l|c|c|}
\hline No. & \multicolumn{1}{|c|}{ Indikator } & $\begin{array}{c}\text { Prosenta } \\
\text { se Skor }\end{array}$ & Kriteria \\
\hline 1. & $\begin{array}{l}\text { Kesesuaian Uraian Materi } \\
\text { Dengan SK dan KD }\end{array}$ & $79,16 \%$ & Sangat Baik \\
\hline 2 & Keakuratan Materi & $91,67 \%$ & Sangat Baik \\
\hline 3 & $\begin{array}{l}\text { Materi Pendukung } \\
\text { Pembelajaran }\end{array}$ & $79,16 \%$ & Sangat Baik \\
\hline 4 & Teknik Penyajian & $95,83 \%$ & Sangat Baik \\
\hline 5 & Penyajian Pembelajaran & $91,66 \%$ & Sangat Baik \\
\hline 6 & $\begin{array}{l}\text { Materi Pendukung } \\
\text { Pembelajaran }\end{array}$ & $89,06 \%$ & Sangat Baik \\
\hline 7 & Jenis Huruf & $91,67 \%$ & Sangat Baik \\
\hline 8 & Letak isi teks & $87,50 \%$ & Sangat Baik \\
\hline 9 & Isi Teks & $91,66 \%$ & Sangat Baik \\
\hline 10 & $\begin{array}{l}\text { Kesesuaian dengan } \\
\text { tingkat perkembangan } \\
\text { mahasiswa }\end{array}$ & $93,75 \%$ & Sangat Baik \\
\hline 11 & Bahasa komunikatif & $93,75 \%$ & Sangat Baik \\
\hline 12 & $\begin{array}{l}\text { Keruntutan dan kesatuan } \\
\text { gagasan }\end{array}$ & $93,75 \%$ & Sangat Baik \\
\hline
\end{tabular}

Dari tabel tersebut dapat dibaca bahwa oleh ahli materi dari 12 indikator dengan butir pertanyaan 35 butir , 100\% penilaian mereka pada kategori sangat baik.Selanjutnya dapat dilanjutkan untuk uji coba produk. Selain penilaian diatas, ahli materi juga memberi masukan, saran dan komentar untuk memperbaiki kualitas produk.

Tabel 4. Saran perbaikan dari ahli materi dan Revisi

\begin{tabular}{|c|l|c|}
\hline No & \multicolumn{1}{|c|}{ Saran } & Revisi \\
\hline 1 & $\begin{array}{l}\text { Kegiatan belajar 4 belum ada } \\
\text { deskripsi kuttab, karena kuttab } \\
\text { masa itu sudah ada dan mata } \\
\text { kuliah sejarah pendidikan islam } \\
\text { salah satu kajian intinya adalah } \\
\text { lembaga pendidikan islam } \\
\text { (Kuttab) }\end{array}$ & Dilaksanakan \\
\hline 2 & $\begin{array}{l}\text { Materi Khulafaur Rosyidin } \\
\text { deskripsinya kurang detail dan } \\
\text { kritis }\end{array}$ & Dilaksanakan \\
\hline 3 & $\begin{array}{l}\text { Referensi kurang representatif } \\
\text { maka perlu diperdalam dengan } \\
\text { referensi yang lebih bagus }\end{array}$ & Dilaksanakan \\
\hline 4 & $\begin{array}{l}\text { Tata tulis diperbaiki seperti kata } \\
\text { islam }\end{array}$ & Dilaksanakan \\
\hline 5 & $\begin{array}{l}\text { Kegiatan belajar 12 ditambahi } \\
\text { materi tentang pendidikan islam } \\
\text { pada masa orde lama, orde baru } \\
\text { dan reformasi }\end{array}$ & Dilaksanakan \\
\hline
\end{tabular}

Penilaian selanjutnya adalah teman sejawat yaitu orang yang secara praktis mengajarkan materi mata kuliah sejarah pendidikan islam,mereka adalah Dosen Sekolah Tinggi Ilmu Tarbiyah Pemalang, beliau adalah Yuliana Habibi M.SI dan Purnama Rozak M.SI. Dari penilaian teman sejawat terhadap 21 indikator dengan 74 butir pertanyaan didapati hasil $100 \%$ mendapat penilaian sangat baik. Selanjutnya dapat dilanjutkan untuk ujicoba produk. Selain memberikan penilaian, teman sejawat memberikan masukan, saran, komentar untuk perbaikan kualitas produk. Hasil Kesimpulannya layak untuk uji coba lapangan dengan revisi sesuai masukan.

Uji coba selanjutnya Uji Coba One to One (Satu lawan satu) pada 3 orang mahasiswa sebagai calon pengguna. Berikut data yang diperoleh pada pelaksanaan uji coba satu lawan satu. Hasil uji coba dari 23 indikator dengan 76 butir pertanyaan adalah $22 \%$ termasuk kategori Baik, $78 \%$ termasuk kategori sangat baik. Sehingga kesimpulannya produk dalam kategori sangat baik. Selanjutnya bisa dilanjutkan pada kelompok kecil setelah memperbaiki dari saran dan masukan dari mahasiswa. Selain penilaian diatas, mahasiswa uji coba satu lawan satu juga memberikan masukan, saran, komentar untuk perbaikan kualitas produk. Revisi telah dilakukan sesuai saran-saran yang relevan. Adapun saran dari responden adalah Tata letak penulis kurang proporsional pada cover modul ,tulisan modul sejarah pendidikan islam pada cover modul kurang jelas, tulisan penerbit pada cover modul terlalu kecil semua saran dari responden dilaksanakan sesuai dengan masukan yang diterima.

Dari saran uji coba one to one pada mahasiswa peneliti melakukan tindak lanjut dari uji coba one to one. Adapun hasil dari tindak lanjut one to one adalah dari 23 indikator dengan 76 butir pertanyaan adalah $100 \%$ termasuk kategori sangat baik, Sehingga kesimpulannya produk dalam kategori sangat baik. Selanjutnya bisa dilanjutkan pada kelompok kecil .Uji Coba Kelompok Kecil

Uji coba kelompok kecil atau small group dilakukan pada responden dengan jumlah 15 Mahasiswa diperoleh hasil terhadap item-item yang dinilai dari 23 indikator dengan 83 butir pertanyaan adalah 91,30\% termasuk kategori sangat baik, dan 8,70\% termasuk kategori baik. Sehingga kesimpulannya produk dalam kategori sangat baik. Selanjutnya bisa dilanjutkan pada kelompok besar. Selain itu, dalam uji coba kelompok kecil mendapatkan saran bahwa Penelitian ini/informasi ini sangat menarik untuk menambah wawasan dan 
pengetahuan, dapat membantu mahasiswa dalam perkuliahan, mengenal bentuk modul sebagai sumber belajar yang dapat memotivasi belajar mahasiswa, menjadi acuan bagi dosen lain untuk mengembangkan sumber belajar yang lain. Uji coba selanjutnya adalah uji coba kelompok besar dilakukan terhadap 30 mahasiswa.

Dari hasil penilaian modul pada kelompok besar dapat disimpulkan bahwa modul yang dikembangkan diperoleh rata-rata dari masing-masing aspek sebagai berikut: Aspek Metode rata-rata skor 85,57\% dengan kategori Sangat Baik, Aspek Bahasa diperoleh skor $84,31 \%$ dengan kategori sangat baik, sedang aspek Grafika diperoleh skor 86,73\% dengan kategori Sangat Baik

Dari data diatas dapat dibaca bahwa produk yang dikembangkan $100 \%$ dengan kategori sangat baik. Dengan ini dapat disimpulkan bahwa produk yang dikembangkan layak untuk digunakan dalam kelas. Selain penilaian diatas, mahasiswa uji coba kelompok besar memberikan masukan, saran, komentar untuk perbaikan kualitas produk. Dengan melakukan perbaikan atau revisi produk diharapkan dapat lebih meningkatkan kualitas produk yang sedang dikembangkan. Revisi telah dilakukan sesuai saran saran yang relevan. Adapun kesan dari mahasiswa adalah Belajar dengan modul menyenangkan karena dapat mengatur cara belajar sesuai kemampuan mahasiswa Sudah baik dan menyenangkan.

Setelah produk diujikan pada kelompok besar, kemudian dilakukan langkah penyebaran produk atau penggunaan produk. Dan untuk mengetahui hasil belajar setelah menggunakan modul, maka dilakukan Evaluasi sumatif .

Evaluasi ini dilakukan untuk menentukan hasil belajar mahasiswa setelah menggunakan modul. Hal ini dilakukan dengan cara pre test dan Post Test. Soal untuk pre test diberikan sebelum menggunakan modul dan soal post test diberikan setelah modul digunakan. Pada Pembelajaran Mandiri Berdasarkan evaluasi belajar yang dilakukan pada pre test dan post test maka diperoleh data

T tabel $\alpha 2,04$ dan $\mathrm{t}$ hitung 7,0445, t hitung $>$ $\mathrm{t}$ table yaitu 7,0445 $>2,04$ maka terdapat signifikan antara sebelum menggunakan modul dengan sesudah menggunakan modul dengan pembelajaran mandiri.

Pembelajaran Konvensional Berdasarkan evaluasi belajar yang dilakukan pada pre test dan post test maka diperoleh data:
$\mathrm{T}$ tabel $\alpha 2,04 \mathrm{t}$ hitung $>\mathrm{t}$ table yaitu 3,987 $>$ 2,04 maka terdapat signifikansi antara sebelum menggunakan modul dengan sesudah menggunakan modul dengan pembelajaran konvensional

Dengan kata lain bahwa Penggunaan modul Sejarah Pendidikan Islam terbukti signifikan terhadap peningkatan hasil belajar Sejarah Pendidikan Islam pada mahasiswa Sekolah Tinggi Ilmu Tarbiyah Pemalang. Hal tersebut dibuktikan dengan rata-rata hasil belajar yang lebih tinggi setelah menggunakan modul dibandingkan dengan sebelum menggunakan modul baik dengan model pembelajaran secara mandiri maupun konvensional.

Implikasi hasil penelitian diharapkan dapat meningkatkan mutu bagi Perguruan Tinggi yaitu Sekolah Tinggi Ilmu Tarbiyah Pemalang baik bagi dosen, mahasiswa dan Ketua serta pejabat dilingkungan Sekolah Tinggi Ilmu Tarbiyah Pemalang . Bagi dosen pengampu mata kuliah sejarah pendidikan islam, pengembangan bahan pembelajaran ini yang berupa modul Sejarah Pendidikan Islam dapat meningkatkan efektifitas pembelajaranya, sehingga pembelajaran akan lebih menarik, mendorong semangat belajar mahasiswa, meningkatkan hasil belajar siswa dan meningkatkan profesionalitas dosen serta memunculkan pemikiran bahwa mengajar tidak hanya transfer pengetahuan saja tapi harus memahami karakteristik mahasiswa yang diajar sehinga berdampak pada proses pembelajaran yang menyenangkan dan hasil yang memuaskan sesuai dengan tujuan yang diharapkan. Bagi Mahasiswa, penerapan pengembangan bahan pembelajaran sejarah pendidikan islam membuat pembelajaran lebih menarik karena mahasiswa dapat belajar sesuai dengan kemampuan dan gaya belajar masing-masing mahasiswa sehingga antusias untuk mempelajarinya sehingga akan berpengaruh pada hasil belajar yang meningkat.

Bagi Ketua Sekolah Tinggi Ilmu Tarbiyah Pemalang dan para pejabat dilingkungan, hasil penelitian ini menjadi masukan sebagai salah satu bahan pertimbangan dan kebijakan, terutama yang berkaitan dengan pembelajaran diperguruan Tinggi, dengan melihat hasil dari efektifitas penggunaan modul Sejarah Pendidikan Islam maka menjadi acuan untuk meningkatkan mutu dosen dalam menyampaikan pembelajaran. Hal ini dapat dilakukan dengan diberikan pelatihan tentang penyusunan modul dengan mengundang tutorial agar terbuka 
wacana bagi dosen pengampu mata kuliah dapat menyusun bahan ajar yang lebih inovatif dan kreatif.

Bagi peneliti lain, hasil penelitian ini diharapkan menjadi acuan untuk mengadakan penelitian lebih lanjut dengan memperbaiki kelemahan yang ada agar lebih baik lagi terhadap hasil penelitian.

\section{KESIMPULAN}

Modul yang dikembangkan sesuai dengan kebutuhan mahasiswa Sekolah Tinggi Ilmu Tarbiyah dalam mempelajari mata kuliah Sejarah Pendidikan Islam dilihat dari segi isi, Penyajian, Bahasa dan Kegrafikan hal ini dibuktikan dengan penilaian yang rata-rata sangat baik.

Diperoleh kesimpulan hasil uji validitas bahwa penggunaan modul Sejarah Pendidikan Islam mampu meningkatkan hasil belajar pada mata kuliah Sejarah Pendidikan Islam atau dapat dikatakan terdapat hubungan yang signifikan terhadap hasil belajar sebelum menggunakan modul dan sesudah menggunakan modul baik dengan model mandiri maupun konvensional.

Modul yang dikembangkan memiliki kelebihan diantaranya bahwa modul yang dirancang tidak hanya digunakan secara mandiri tetapi juga secara konvensional atau dengan kehadiran dosen yang membimbingnya. Hal ini berdampak pada pola belajar mahasiswa, yaitu mahasiswa dapat belajar menurut kecepatan masing-masing tidak terpaku pada apa yang disampaikan oleh dosen pengampu.

Hasil penelitian ini menghasilkan modul cetak yang dirancang sesuai kebutuhan mahasiswa, tetapi memiliki kelemahan diantaranya karena bentuknya cetak yang terbuat dari kertas maka modul ini tidak tahan pada air menjadikan mudah rusak.

\section{DAFTAR RUJUKAN}

Harlock, Elizabeth. Psikologi Perkembangan Suatu Pendekatan Sepanjang Rentang kehidupan edisi V. Jakarta: Erlangga, 2006.

Majid, Abdul., (Perencanaan Pembelajaran Mengembangkan standar Kompetensi Guru, Bandung : Remaja Rosdakarya, 2011.

Miarso, Yusufhadi. Menyemai Benih Teknologi Pendidikan. Jakarta: Prenada Media Group, 2011.

Muslich, Masnur.Text Book Writing Dasar- dasar Pemahaman, Penulisan dan Pemakaian Buku
Teks, Jogjakarta : AR Ruzz Media, 2010.

Nasution, Berbagai pendekatan dalam proses belajar mengajar. Jakarta: Bumi Aksara, 2008.

Prastowo, Andi, Panduan Kreatif Membuat Bahan Ajar Inovatif. Yogyakarta: Diva Press, 2011.

Purwanto, Aristo Rahadi, Suharto Lasmono. Pengembangan Modul. Jakarta: Pustekkom, 2007.

Sitepu, B.P. Penyusunan Buku Pelajaran. Jakarta : Verbum Publising,2006.

Sitepu, B.P. Penulisan Buku Teks Pelajaran,Bandung: Remaja Rosdakarya,2012.

Smaldino, Sharon E.,Deborah L. Lowther, dan James D. Russell. Instructional Technology \& Media for learning"Teknologi Pembelajaran dan Media untuk Belajar", terjemahan Arif Rahman.Jakarta : Prenada Media Group.2011.

Suparman, M. Atwi. Desain Instruksional. Jakarta: Universitas Terbuka, 2004

Desain Instruksional Modern

(Jakarta: Erlangga,2012) 